\title{
SYNTHESIS AND STUDY OF THE PROPERTIES OF MAGNETICALLY SEPARABLE NANOPHOTOCATALYST BiFeO
}

\author{
F.F. Orudzhev ${ }^{1}$, N.M-R. Alikhanov ${ }^{1,2}$, M.Kh. Rabadanov ${ }^{1}$, Sh.M. Ramazanov ${ }^{1}$, A.B. Isaev ${ }^{1}$, \\ S.Kh. Gadzhimagomedov ${ }^{1}$, A.Sh. Aliyev ${ }^{3}$, V.R. Abdullaev ${ }^{1}$ \\ ${ }^{1}$ Dagestan State University \\ Gadzhieva Str. 43-a, Makhachkala, 367000, Republic of Dagestan, Russia.e-mail: ff.orudzhev@dgu.ru \\ ${ }^{2}$ Institute of Physics, Dagestan Science Center Russian Academy of Sciences \\ Yaragskogo Str. 94,Makhachkala, 367000, Republic of Dagestan, Russia \\ ${ }^{3}$ Institute of Catalysis and Inorganic Chemistry named after Acad. M. Nagiev \\ H.Javid ave., 113, Baku, AZ 1143, Azerbaijan Republic, e-mail:akifaliyev55@mail.ru
}

Received 14.11.2018

\begin{abstract}
The magnetically separable nanophotocatalyst $\mathrm{BiFeO}_{3}$ were synthesis via facile one-step the selfpropagating combustion of solutions method. It is shown that this method can be used to synthesize a phase homogeneous and nanosized powder with a $\mathrm{BiFeO}_{3}$ phase purity 99\%. The effect of heat treated temperature on the morphology, structure and optical properties of $\mathrm{BiFeO}_{3}$ is investigated. The optimal parameters of heat treating temperature for the application of $\mathrm{BiFeO}_{3}$ as a photocatalyst are established. Using Mulliken's electronegativity theory, a possible mechanism of methyl orange (MO) decomposition was established. It is shown that the most probable is the oxidation of MO by hydroxyl radicals.
\end{abstract}

Keywords: bismuth ferrite, nanophotocatalysis, combustion, magnetic separation, electronegativity, hydroxyl radicals, propellant chemistry.

\section{INTRODUCTION}

Water pollution is one of the biggest problems that developing countries face, and researchers from all over the world make various attempts to solve these problems [1-3]. The wastewater from various industries, such as textiles and pharmaceuticals, are becoming a big threat to the environment [4]. Some wastewaters are toxic to aquatic organisms, and some dyes from the textile industry can become carcinogenic by undergoing anaerobic bleaching [5, 6]. Therefore, there is a strict need for wastewater treatment before it is discharged into water bodies.

Of all the methods of wastewater treatment, photocatalysis is a very promising technology, since light energy is used to purify wastewater. Photocatalysis is as follows: when the light of energy equal to or exceeding the band gap of a semiconductor hits its surface, an electron-hole pair arises, they diffuse to the surface of the catalyst, subjecting the compounds adsorbed to the surface to redox reactions.

However, the separation and recycling of photocatalysts in powdered form is extremely complex. This not only leads to the loss of the photocatalyst but also to secondary contamination by the nanoparticles of the photocatalyst [7]. This difficulty is easily overcome with the help of magnetically separable photocatalysts $[8,9] . \mathrm{BiFeO}_{3}$ is a widely studied photocatalyst because it exhibits multiferroic properties at room temperature, which promotes efficient separation of charge carriers and has a rather high chemical stability [10-13]. $\mathrm{BiFeO}_{3}$ is obtained in various ways, such as sol-gel, hydrothermal, hydrothermal-microwave, chemical coprecipitation, burning [14-17]. However, one of the fundamental problems of 
obtaining $\mathrm{BiFeO}_{3}$ is the problem of phase purity. In addition, since photocatalysis is a surface phenomenon, particles with a smaller size and higher surface area show greater photocatalytic activity. From the analysis of the above works, we can conclude that the method of synthesis plays an important role in the photocatalytic activity. Based on this, we have proposed in this paper a method for producing nanoscale $\mathrm{BiFeO}_{3}$ using the of selfpropagating solution combustion synthesis method (SPSC). The SPSC method is simple, economical and efficient in terms of the quality of the product obtained. SPSC is based on a fast and self-sustaining redox reaction between fuel and oxidant in the presence of metal cations. In our case, metal nitrates were used as an oxidizing agent, and glycine, capable of forming complexes with metal cations, served as the fuel. However, in the existing works on the synthesis of $\mathrm{BiFeO}_{3}$, $\mathrm{HNO}_{3}$ was additionally added as an oxidizing agent [18]. The advantage of our method is that we did not use any additional oxidizing agent and, thus, excluded one of the factors for the appearance of undesirable other phases.

\section{EXPERIMENTAL PART}

Nanoparticles of $\mathrm{BiFeO}_{3}$ were obtained using a new method of synthesis. Analytically pure bismuth nitrates $\mathrm{Bi}\left(\mathrm{NO}_{3}\right)_{3} \cdot 5 \mathrm{H}_{2} \mathrm{O}$, iron $\left(\mathrm{Fe}\left(\mathrm{NO}_{3}\right)_{3} \cdot 9 \mathrm{H}_{2} \mathrm{O}\right)$ and glycine were taken according to the stoichiometric ratio. Glycine played the role of fuels, which provided a platform for redox reactions between reagents during combustion. Metal nitrates are hygroscopic, and they tend to form a suspension mixture when mixed with glycine. The mixture was dehydrated by heating to 315 ${ }^{\circ} \mathrm{C}$. The dried mixture was then heated on a hot stove to initiate the combustion process. Since metal nitrates also play the role of oxidizing agents, the combustion process can occur efficiently using oxygen contained in the reactants themselves. As a result of the combustion process, the ash was formed and yellow vapor was released. Then the ash was carefully ground in a mortar. Then the sampleheat treated at temperatures of 450 , 550,600 and $650{ }^{\circ} \mathrm{C}$ for an hour.

X-ray diffraction studies were performed using an Empyrean PANalytical Xray diffractometer in the radiation of a copper anode with a nickel filter. Data processing was performed using the High Score Plus application program, included in the instrument software, and the diffraction database PDF-2. The crystallite sizes were calculated using the Debye-Scherer formula from the broadening of the reflexes on diffractograms:

$$
\mathrm{d}=\frac{\mathrm{k} \lambda}{\beta \cos \theta^{\prime}}
$$

where, $d$ is the average crystallite size, $\lambda$ is the wavelength of the used radiation $\lambda(\mathrm{CuK \alpha})=$ $0.154051 \mathrm{~nm}, \beta$ is the peak width at half height, $\theta$ is the diffraction angle, $\mathrm{k}=0.9$.

Diffuse reflection spectra in the coordinates $F(R)=f(\lambda, n m)$, where $F(R)$ is the Kubelka-Munk function, were performed on a Shimadzu UV-3600 spectrophotometer with an integrating sphere LISR-3100. To determine the width of the band gap of the obtained materials, we used the method of constructing the Kubelka-Munk curve by converting the optical absorption spectra using the values of the absorption coefficient $(\mathrm{K})$ and the photon energy $(h v)$ using the wavelengths: $(h v=1240 / \lambda)$. The graph was plotted in coordinates $(\mathrm{K} h v)^{1 / 2}$ to $(h v)$ and by extrapolating of the curve to the zero value of the absorption coefficient, find the energy value of the band gap.

The morphology of the obtained samples was studied using an ASPEX EXpress TM scanning electron microscope with a microprobe elemental analyzer. The voltage on the accelerating electrode was varied from 10 to $30 \mathrm{kV}$ with a step change of $10 \mathrm{~V}$. The morphology was studied in the mode of detection of secondary electrons.

The photocatalytic characteristics of the catalysts were evaluated by photodegradation of methyl orange (MO) in an 
aqueous solution $(0.015 \quad \mathrm{mmol} / \mathrm{l})$. Photocatalytic experiments were carried out in a $100 \mathrm{ml}$ quartz cell. As the light sourcethehigh pressure mercury lamp with a power of $250 \mathrm{~W}$ was used. A constant cell temperature of $26{ }^{\circ} \mathrm{C}$ was maintained by air ventilation and monitored with a thermometer. For the photocatalytic reaction, $25 \mathrm{mg}$ of photocatalyst was added to $50 \mathrm{ml}$ of an aqueous solution of MO (0.015 mmol / 1). Before turning on the light, the cell was placed in the dark for 30 minutes to achieve adsorption equilibrium. Before start of experiment, the suspension was subjected to ultrasonic treatment to degas the photocatalyst. The whole process was carried out with magnetic stirring. Sampling $(5 \mathrm{ml})$ was carried out every 10 minutes, large particles of the nanopowder were subjected to magnetic separation using a powerful neodymium magnet to prevent loss of the photocatalyst, then centrifuged at $14000 \mathrm{rpm}$ for 3 minutes on an MR23i JOUAN (Thermo Fisher Scientific) high-speed refrigeration centrifuge for deposition of ultrafine nanoparticles. The concentration of MO was measured using a Beckman Coulter DU730 series UV/Vis spectrophotometer at a constant temperature of $26{ }^{\circ} \mathrm{C}$. After measurement, the solution was poured back into the cell and the process continued. For comparison, we also tested the MO solution under similar conditions, without a photocatalyst.

The concentration of MO was determined by the Bouguer-Lambert-Beer law:

$$
\varepsilon=\frac{A}{l C},
$$

where $\varepsilon$ is the molar extinction coefficient (23 200), A is the optical density, 1 is the length of the optical path.

\section{RESULTS AND DISCUSSIONS}

The SPSC process consists of three main stages, such as (1) the formation of a combustion mixture (2) the formation of a gel (3) the burning of a gel.
The first step in the synthesis process is the formation of a coordination complex of metal ions with glycine, since the latter is a complexing agent:

$$
\begin{aligned}
& \mathrm{Bi}\left(\mathrm{NO}_{3}\right)_{3} \cdot 5 \mathrm{H}_{2} \mathrm{O}+\mathrm{Fe}\left(\mathrm{NO}_{3}\right)_{3} \cdot 9 \mathrm{H}_{2} \mathrm{O}+\mathrm{NH}_{2} \mathrm{CH}_{2} \mathrm{COOH} \rightarrow \mathrm{Bi}\left[\mathrm{Fe}\left(\mathrm{NH}_{2} \mathrm{CH}_{2} \mathrm{COO}\right)\right]\left(\mathrm{NO}_{3}\right)_{3} \cdot \mathrm{H}_{2} \mathrm{O}+ \\
& \mathrm{NO}_{2}+\mathrm{H}_{2} \mathrm{O}
\end{aligned}
$$

Nitrate ions in the complex itself provide the process of burning with the

necessary oxygen. When heated, the complex is reduced to bismuth and iron oxides:

$$
\mathrm{Bi}\left[\mathrm{Fe}\left(\mathrm{NH}_{2} \mathrm{CH}_{2} \mathrm{COO}\right)\right]\left(\mathrm{NO}_{3}\right)_{3} \cdot \mathrm{H}_{2} \mathrm{O} \rightarrow \mathrm{Bi}_{2} \mathrm{O}_{3}+\mathrm{Fe}_{2} \mathrm{O}_{3}+\mathrm{NO}_{2}+\mathrm{H}_{2} \mathrm{O}+\mathrm{CO}_{2}
$$

$\mathrm{Bi}$ and $\mathrm{Fe}$ oxides interact with the formation of $\mathrm{BiFeO}_{3}$ :

$$
\mathrm{Bi}_{2} \mathrm{O}_{3}+\mathrm{Fe}_{2} \mathrm{O}_{3} \rightarrow 2 \mathrm{BiFeO}_{3}
$$

Due to the fact that the temperature in the reaction chamber is unevenly distributed over the whole volume, the solid-phase reaction between $\mathrm{Bi}_{2} \mathrm{O}_{3}$ and $\mathrm{Fe}_{2} \mathrm{O}_{3}$ is nonstoichiometric. This is mainly due to the formation of impurity phases. Given that when burning a glycine-nitrate mixture, the main gaseous reaction products are $\mathrm{N}_{2}, \mathrm{CO}_{2}$ and $\mathrm{H}_{2} \mathrm{O}$ [19], the overall empirical redox reaction can be expressed as follows:

$\mathrm{Bi}\left(\mathrm{NO}_{3}\right)_{3} \cdot 5 \mathrm{H}_{2} \mathrm{O}+\mathrm{Fe}\left(\mathrm{NO}_{3}\right)_{3} \cdot 9 \mathrm{H}_{2} \mathrm{O}+3.33 \mathrm{NH}_{2} \mathrm{CH}_{2} \mathrm{COOH} \rightarrow \mathrm{BiFeO}_{3}+4.66 \mathrm{~N}_{2}+22.33 \mathrm{H}_{2} \mathrm{O}+$ $6.66 \mathrm{CO}_{2}$

The stoichiometry of the combustion reaction was calculated using the concepts of propellant chemistry [20], which shows a simple method for calculating the redox valences of the mixture components. According to these concepts, metals, carbon 
and hydrogen are considered as reducing elements with corresponding metal valences, +4 for carbon and +1 for hydrogen. Oxygen is considered as an oxidizing agent with a valence of -2 , and the valence of nitrogen is 0 . In the case of burning the nitrate-glycine mixture, the total calculated valence of metal nitrates by arithmetic summing up the oxidative and reducing valences was -30 . Glycine valence was +9 . Based on the calculation of the stoichiometry of the redox nitrate-glycine mixture by the formula $1 \cdot(-30)$ $+\mathrm{n} \cdot(+9)=0$, it was found that the reaction requires $\mathrm{n}=3.33 \mathrm{~mol}$ of glycine.

The combustion reaction is highly exothermic, and the maximum combustion temperature is achieved when the equivalence ratio $\left(\left(\phi_{\mathrm{e}}\right.\right.$ is the oxidizer/fuel relation) is equal to unity. The equivalence relation was found according to [21]

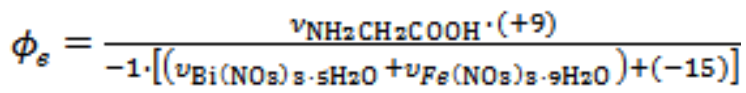

In this work, we synthesized $\mathrm{BiFeO}_{3}$ precisely at $\phi_{\mathrm{e}}=1$. The resulting $\mathrm{BiFeO}_{3}$ nanopowder was heat treated at $450,550,600$, and $650{ }^{\circ} \mathrm{C}$.
To study the morphology, images were taken on a scanning electron microscope. The SEM images are shown in Figure 1.
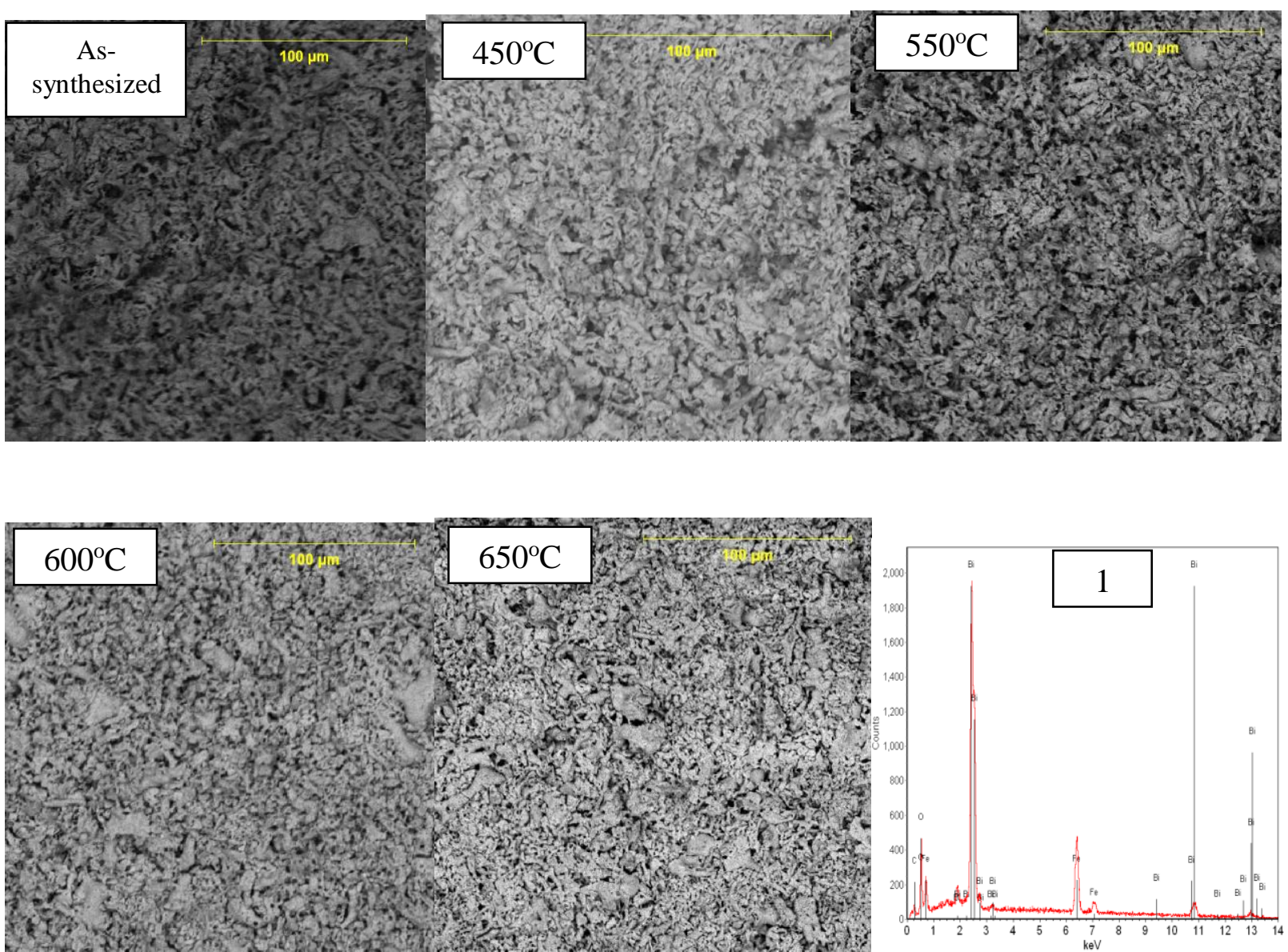

Fig. 1. SEM images of as prepared andheat treated at different temperatures $\mathrm{BiFeO}_{3}$ nanopowders. 1 - EDX spectra of $\mathrm{BiFeO}_{3}$ sample $\left(600^{\circ} \mathrm{C}\right)$. 
From the images it is clear that the samples are nanopowder agglomerated in a highly porous structure. The presence of pores is associated with a feature of the synthesis technique and is characterized by the process of emitting a large amount of gases, which is clearly seen from the reaction equation (6). It can also be noted that with an increase in the heat treatingtemperature, the nanopowder is aggregated and compacted by sintering smaller particles, and the surface area obviously decreases, which may adversely affect the photocatalytic properties.

On the EDX spectra of elemental analysis, it was shown that the powder contains no impurities. The presence of a carbon peak is associated with a particular analysis technique.

The results of XRD X-ray diffraction studies at room temperature for $\mathrm{BiFeO}_{3}$ nanopowders are presented in Figure 2.

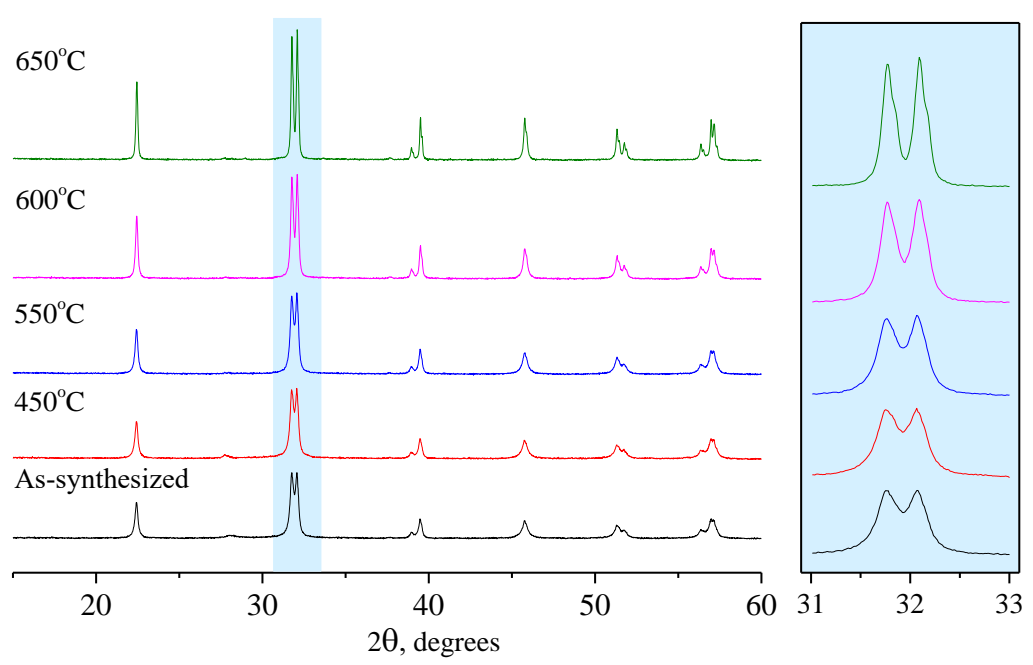

Fig. 2. XRD patterns of as prepared and heat treated at $450,550,600$ and $650{ }^{\circ} \mathrm{C}$ nanopowder $\mathrm{BiFeO}_{3}$.

It can be seen from the figure that all diffraction peaks belong to the distorted rhombohedral structure of $\mathrm{BiFeO}_{3}$ with spatial symmetry R3c. The crystallite sizes, calculated by Scherer formula (1), were approximately $39.6 \mathrm{~nm}, 42 \mathrm{~nm}, 45.7 \mathrm{~nm}, 56.3 \mathrm{~nm}$ and 74.8 $\mathrm{nm}$ for as-synthesized $\mathrm{BiFeO}_{3}$ and heat treated at temperatures of $450{ }^{\circ} \mathrm{C}, 550{ }^{\circ} \mathrm{C}, 600{ }^{\circ} \mathrm{C}$, $650{ }^{\circ} \mathrm{C}$, respectively.

As can be seen, as the heat treatingtemperature increases, the powder recrystallizes. The data obtained confirm the results of research on a scanning electron microscope. In addition to the main phase $\left(\mathrm{BiFeO}_{3}\right)$, diffraction patterns show peaks related to side phases $\left(\mathrm{Bi}_{25} \mathrm{FeO}_{4} 0 \quad \theta \sim 28.1^{\circ}\right.$, $\left.\mathrm{Bi}_{2} \mathrm{Fe}_{4} \mathrm{O}_{9} \theta \sim 28.1^{\circ}-29.1^{\circ}\right)$. In the freshly synthesized powder, the share of side phases is about $7 \%$, with the growth of the heat treatingtemperature $\left(450{ }^{\circ} \mathrm{C}, 550{ }^{\circ} \mathrm{C}, 600{ }^{\circ} \mathrm{C}\right)$, their share decreased to $5 \%, 3 \%$ and $1 \%$, respectively. Further heat treated at $650{ }^{\circ} \mathrm{C}$ leads to its increase to $\sim 10 \%$, and above 650 ${ }^{\circ} \mathrm{C}$ to the decomposition of the main phase and, accordingly, to an increase in the share of side phases. The inset to Figure 2 shows a clear separation of the peaks (104) and (110) at about $32^{\circ}$ with increasing heat treating temperature, which confirms the distorted rhombohedral structure of R3c.

The dependence of $\mathrm{BiFeO}_{3}$ optical properties from heat treating temperatures were determined by diffuse reflectance spectra in the Kubelka-Munk coordinates, corresponding to absorption. The data are presented in Figure 3. 

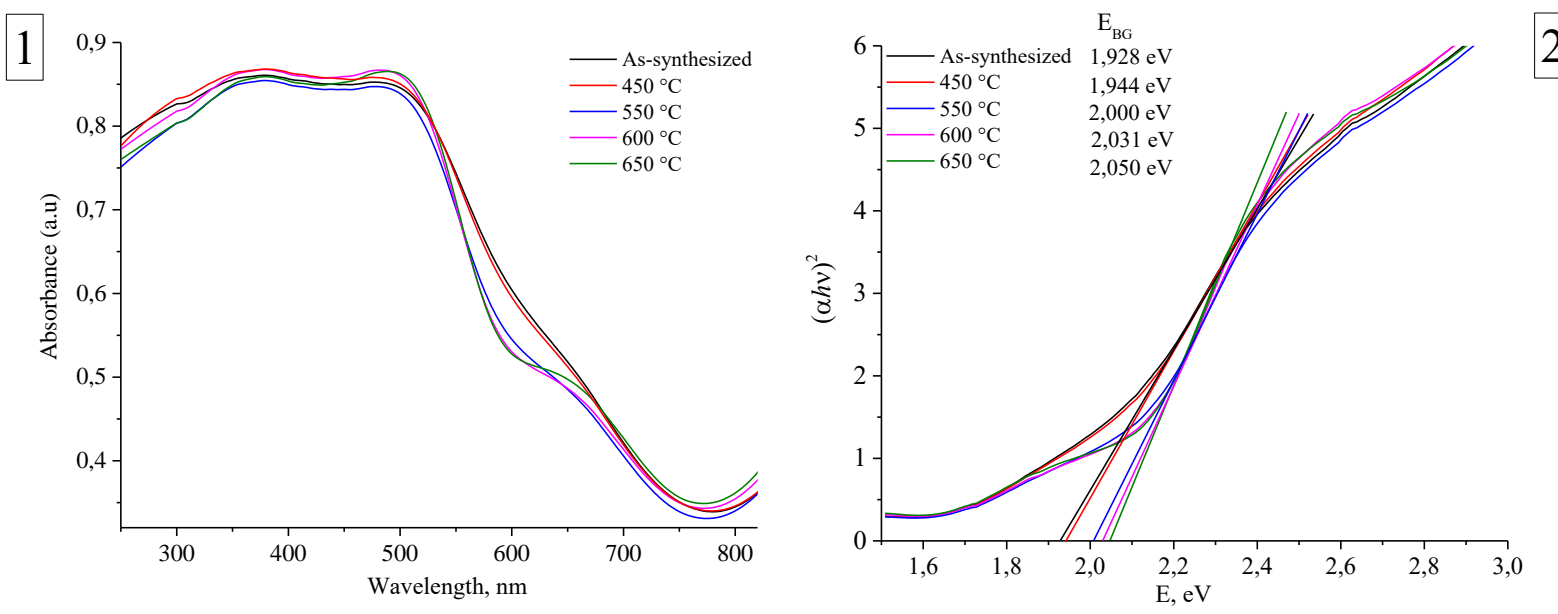

Fig. 3. UV-vis spectra (1) and Tauc plots (2) of $\mathrm{BiFeO}_{3}$ samples heat treated at different temperature $\left({ }^{\circ} \mathrm{C}\right)$.

From Fig. 3 (1) it is seen that an increase in the heat treating temperature leads to displacement of the absorption edge to a shorter wavelength region. The results of experimental studies of the optical band gap, photoconductivity, and linear and nonlinear optical properties [22-24] showed that $\mathrm{BiFeO}_{3}$ is a direct-gap semiconductor with a direct interband transition (2.17-2.81 eV). Considering this, the values of the optical width of the samples band gap were determined by constructing the Taucplots. The result is shown in Figure 3 (2). It can be seen that with an increase in the heat treating temperature, the band gap of the samples slightly increases. The change in the band gap can be associated with the rearrangement of molecular orbitals and the distortion in the $\mathrm{FeO}_{6}$ octahedron [25].

For the obtained $\mathrm{BiFeO}_{3}$ samples, the photocatalytic activity was determined during the oxidation of the methyl orange (MO). In order to eliminate the effect of photolysis of MO under the action of UV-VIS radiation, the experiment without photocatalyst was carried out. Figure 4 shows the absorption spectra of the initial solution of MO and the solution of MO after 3 hours of irradiation.

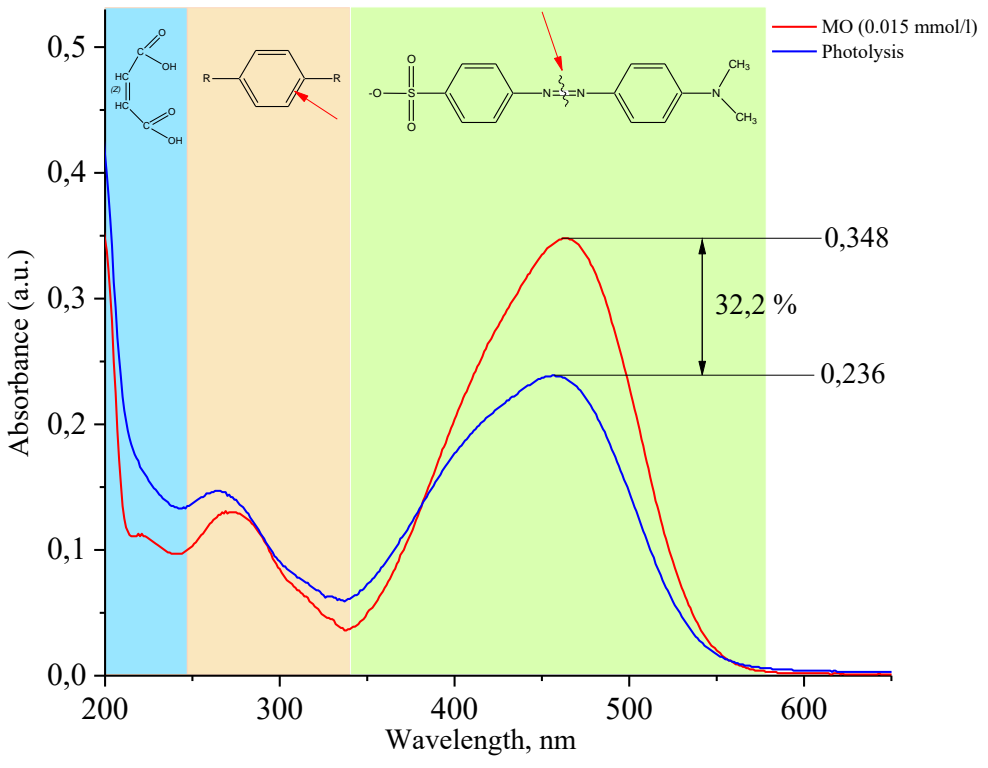

Fig. 4. The adsorption spectra of the initial solution $\mathrm{MO}$ and the solution $\mathrm{MO}$ after 3 hours the UV-VIS irradiation. 
The process of oxidation of MO means that molecular conjugate chains are gradually reduced $[9,26]$. The oxidation of $\mathrm{MO}$ is usually associated with the cleavage of the azogroup, the destruction of the benzene ring, and the formation of small inorganic molecules. These stages can be described as discoloration, degradation and mineralization. Based on these three processes, the oxidation spectra of methylene orange in the region from $200 \mathrm{~nm}$ to $600 \mathrm{~nm}$ can be divided into three sectors:

1. Sector I refers to the wavelength range from 200 to $240 \mathrm{~nm}$, corresponding to the absorption of unsaturated aliphatic acids, and reflecting the process of mineralization.

2. Sector II refers to the wavelength range from 240 to $340 \mathrm{~nm}$, which characterizes
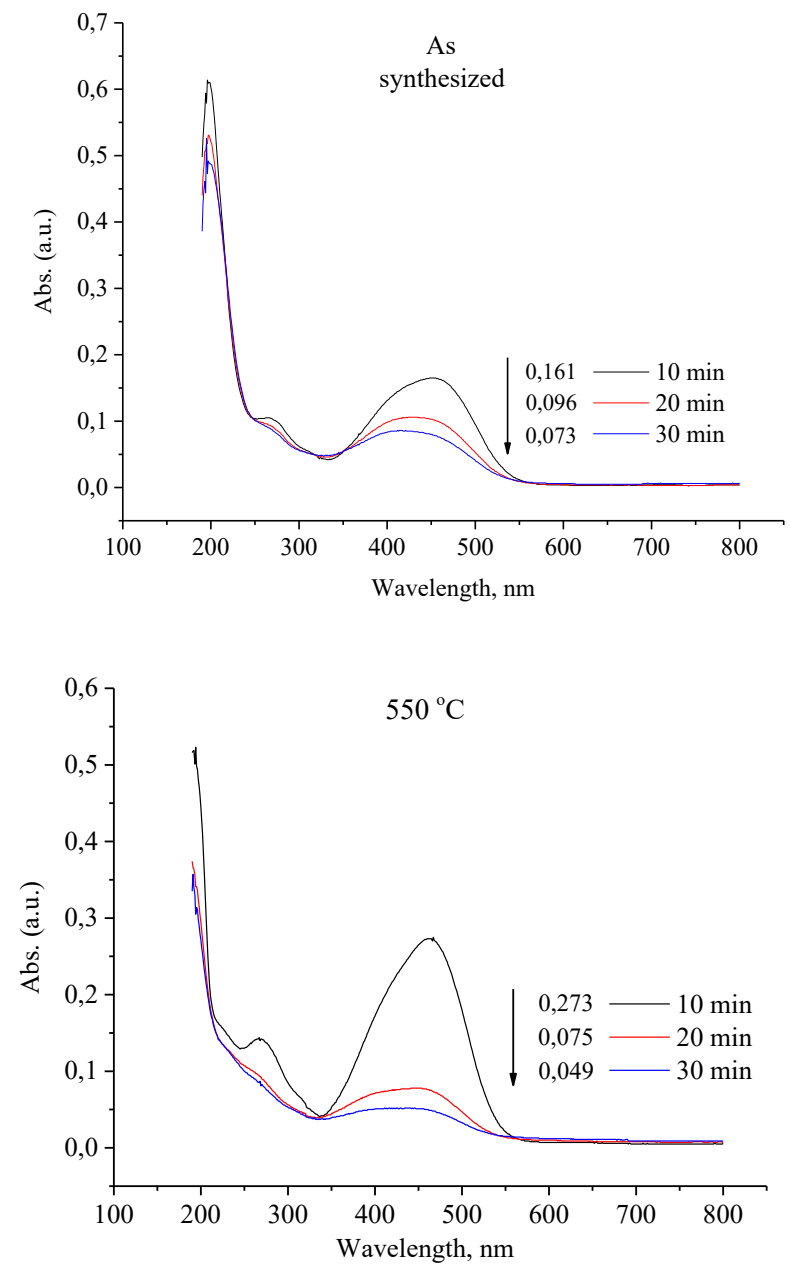
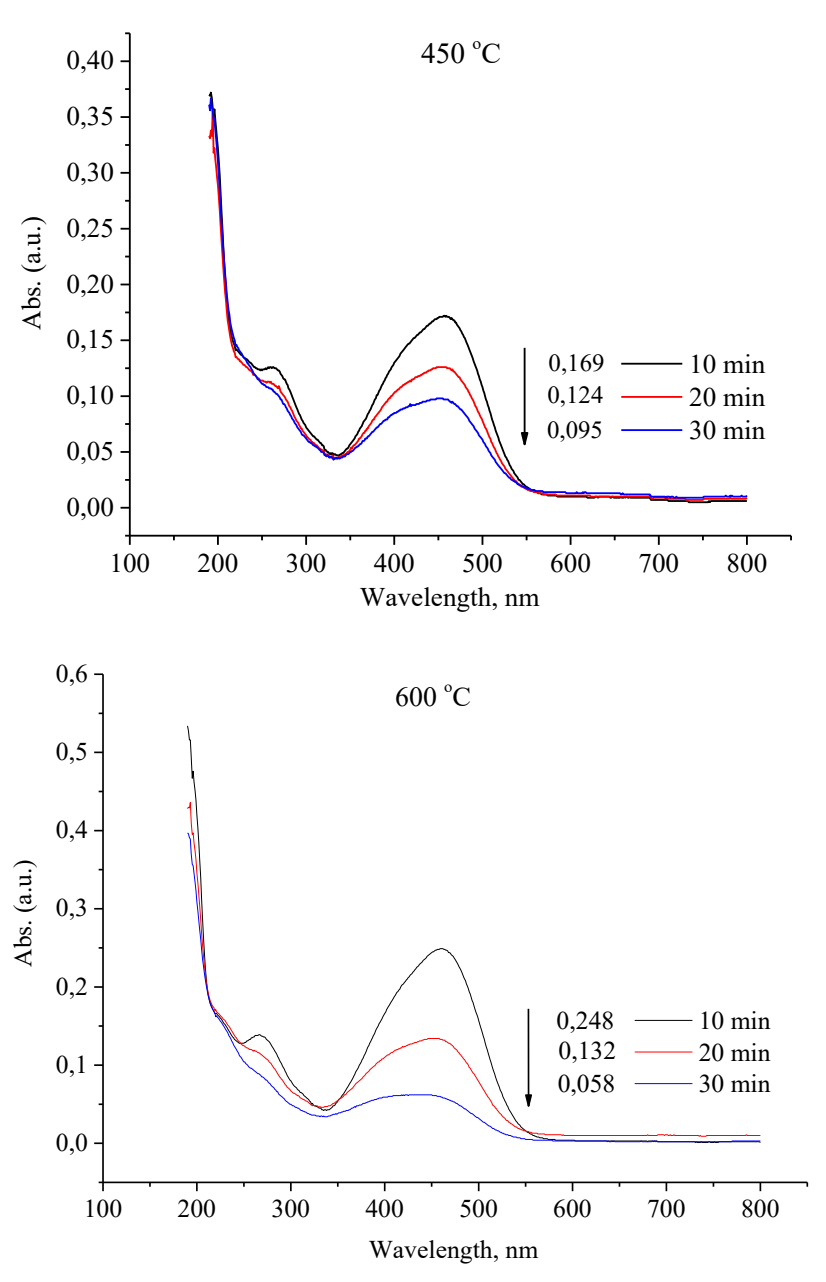

the presence of aromatic rings, and reflects the process of degradation.

3. Sector III refers to the wavelength range from 340 to $580 \mathrm{~nm}$, characterized by the presence of $-\mathrm{N}=\mathrm{N}-$ bonds, the dynamics in which reflects the discoloration process.

As can be seen, after three hours of irradiation, the concentration of the MO solution decreased by $32.2 \%$. At the same time, it should be noted that the peaks at 200240 and $240-340 \mathrm{~nm}$ increase, which indicates that the $-\mathrm{N}=\mathrm{N}-$ bond of MO molecules is broken and a large number of intermediate aromatic and aliphatic molecules are formed.

The photocatalytic oxidation of methyl orange was investigated. The data are presented in Figure 5. 


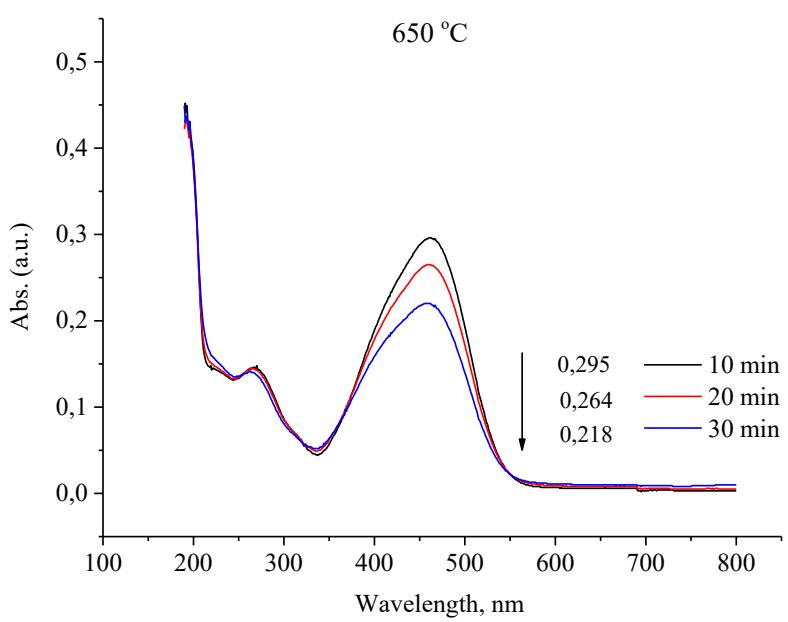

Fig. 5. The adsorption spectra of $\mathrm{MO}$ for $\mathrm{BiFeO}_{3}$ samples heat treated at different temperature

From figure 5 it can be seen that for all samples the process of discoloration and degradation takes place in the first half hour. The greatest photocatalytic activity was shown by bismuth ferrite heat-treated at $550{ }^{\circ} \mathrm{C}$. Smaller PK activity was shown by BFO heat treated at $650{ }^{\circ} \mathrm{C}$. This effect, in our opinion, may be due to several reasons:

- first, heat treated at $650{ }^{\circ} \mathrm{C}$, the powder had a high density and large crystallite sizes, and since photocatalysis is a surface process, the reduction in specific surface area will limit the photocatalytic activity.

- secondly, this may also be associated with an increase in the optical width of the band gap, which makes the photocatalytic process less efficient.

According to the data obtained, the kinetic curves were constructed and the rate constants of the photocatalytic oxidation of MO were determined using the linear approximation method in semi-logarithmic coordinates. The results are presented in Figure 6.

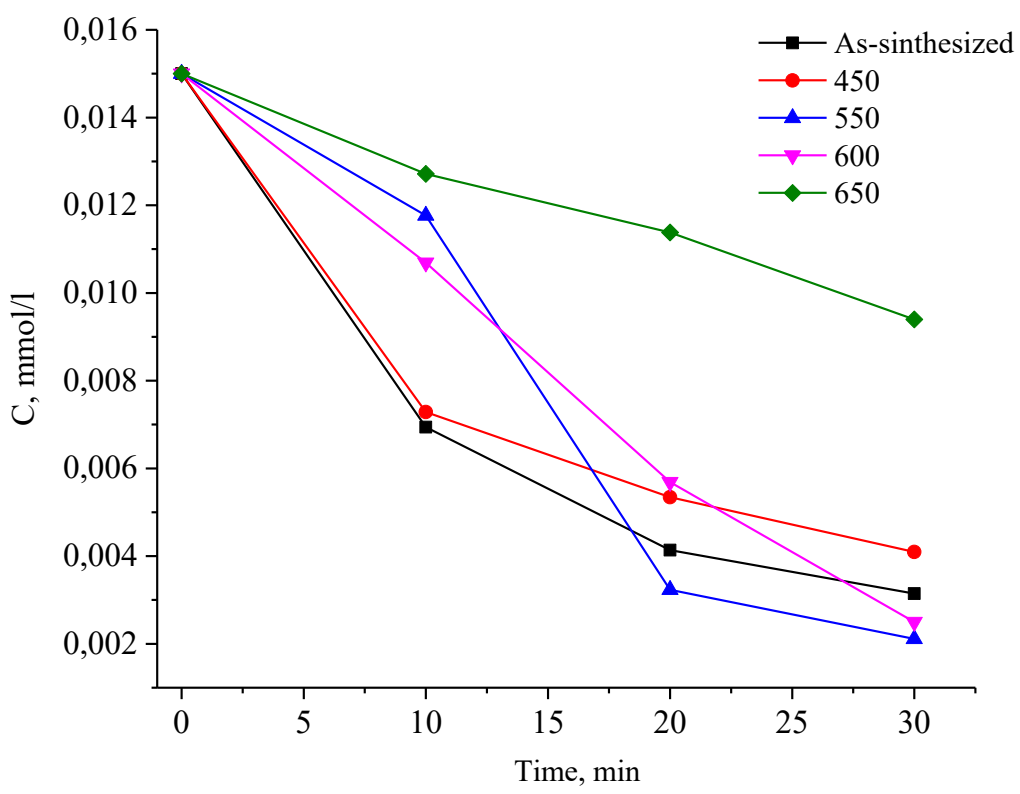

Fig. 6. Photocatalytic oxidation of $\mathrm{MO}$ under UV-VIS light irradiation on $\mathrm{BiFeO}_{3}$ heat treated at different temperature $\left({ }^{\circ} \mathrm{C}\right)$ 


\section{About the mechanism of photocatalysis}

The generation of highly active oxidizing agents is closely related to the potential energy of the conduction band (CB) and the valence band (VB) of a semiconductor. The potentials of the $\mathrm{CB}$ and $\mathrm{VB} \mathrm{BiFeO}_{3}$ were determined using the Mulliken electronegativity theory [27].

$$
\begin{gathered}
\mathrm{E}_{V B}=\mathrm{X}-\mathrm{E}^{e}+0,5 \mathrm{E}_{B G} \\
\mathrm{E}_{C B}=\mathrm{E}_{V B}-\mathrm{E}_{B G}
\end{gathered}
$$

where $E_{\mathrm{VB}}$ is the potential of the valence band, $X$ is the electronegativity of the semiconductor, $\chi$ is the electronegativity of the element, $E^{\mathrm{e}}$ is the standard potential of the hydrogen electrode $(\sim 4.5 \mathrm{eV}), \mathrm{E}_{\mathrm{BG}}$ is the optical width of the band gap, $E_{\mathrm{CB}}$ is the potential of the conduction band.

In this case, the electronegativity of the semiconductor was calculated according to equation (10):

$$
X_{\left(B i F 0_{g}\right)}=\left(\chi(B i)^{1} \cdot \chi(F e)^{1} \cdot \chi(0)^{3}\right)^{\frac{1}{1+1+1}}
$$

and the electronegativity of a neutral atom according to Mulliken is the arithmetic average of the electron affinity $\left(\mathrm{E}_{\mathrm{EA}}\right)$ and the first ionization potential $\left(\mathrm{E}_{\mathrm{i}}\right)$ :

$$
\chi=\frac{\mathrm{E}_{\mathrm{i}}+\mathrm{E}_{E A}}{2}
$$

Since the values of ionization potentials and electron affinity for most atoms are listed in tables [28, 29], Mulliken's electronegativity becomes a parameter with absolute electronegativity values based only on measurable physical quantities. In a sense, Mulliken's electronegativity is the electrochemical potential of an electron in a neutral atom. When atoms combine to form compounds, the charge will flow until the electrochemical potentials (electronegativity) are equalized. For a semiconductor, the volume electronegativity corresponds to the undoped Fermi level or is located midway between the bottom of the conduction band and the top of the valence band.

From the foregoing, the potential of the $\mathrm{VB}$ of the photocatalyst $\mathrm{BiFeO}_{3}$ was calculated as $2.41 \mathrm{eV}$, and the potential of the $\mathrm{CB}$ was $0.49 \mathrm{eV}$. The layout of the energy levels is shown in Figure (7).

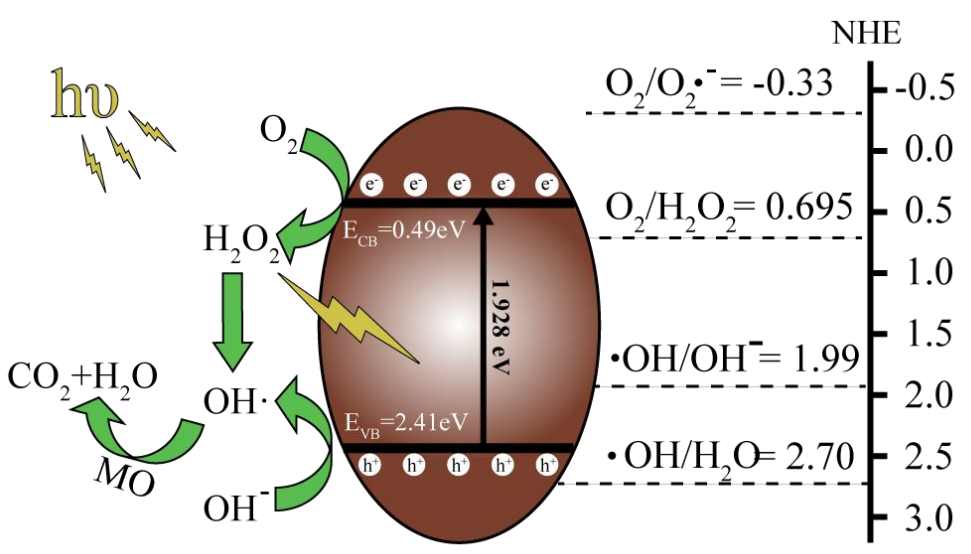

Fig. 7. Schematic diagram energy levels of $\mathrm{BiFeO}_{3}$ and the possible mechanism of light excited oxidation of $\mathrm{MO}$

When $\mathrm{BiFeO}_{3}$ is irradiated with light with energy comparable to or greater than the width of the band gap, an electron-hole pair $\mathrm{h}^{+}$ $\mathrm{e}^{-}(12)$ are generated.

$$
B F O+h v \rightarrow h^{+}+e^{-}
$$

Electrons in the $\mathrm{CB} \mathrm{BiFeO}_{3}$ cannot reduce $\mathrm{O}_{2}$ to $\mathrm{O}^{-}$, , because the $\mathrm{CB}$ potential of $\mathrm{BiFeO}_{3}(0.41 \mathrm{eV}$ vsNHE) is more positive than the standard redox potential $\mathrm{E}^{\theta}\left(\mathrm{O}_{2} / \mathrm{O}^{--}\right)$ $(-0,33 \mathrm{eV}$ vsNHE). However, the potential of $\mathrm{CB} \mathrm{BiFeO}_{3}$ is more negative than the standard 
redox potential $\mathrm{E}^{\theta}\left(\mathrm{O}_{2} / \mathrm{H}_{2} \mathrm{O}_{2}\right)(0.685 \mathrm{eV}$ vsNHE) [30], therefore, oxygen adsorbed on the surface of the semiconductor will react with two electrons to form $\mathrm{H}_{2} \mathrm{O}_{2}$ (13), which subsequently interacts with an electron and forms $\cdot \mathrm{OH}(14)$.

$$
\begin{aligned}
& \mathrm{O}_{2}+2 \mathrm{e}^{-}+2 \mathrm{H}^{+} \rightarrow \mathrm{H}_{2} \mathrm{O}_{2} \\
& \mathrm{H}_{2} \mathrm{O}_{2}+\mathrm{e}^{-} \rightarrow \cdot \mathrm{OH}+\mathrm{OH}^{-}
\end{aligned}
$$

The potential of the $\mathrm{VB} \mathrm{BiFeO}_{3}$
$\mathrm{eV}$ vsNHE) is more positive than the standard redox potential $\mathrm{E}^{\theta}\left(\cdot \mathrm{OH} / \mathrm{OH}^{-}\right)(1.99 \mathrm{eV}$ vsNHE), which indicates that holes in the VB can oxidize adsorbed $\mathrm{OH}^{-}$with the formation of $\cdot \mathrm{HO}(15)$

$$
\mathrm{OH}_{\mathrm{ads}}+\mathrm{h}^{+} \rightarrow \cdot \mathrm{OH}
$$

Thus, we can conclude that the main route of decomposition of MO is oxidation by hydroxyl radicals, although some holes localized on the surface will also interact with organic compounds.

\section{CONCLUSION}

$\mathrm{BiFeO}_{3}$ nanopowders with high phase homogeneity were synthesized using the selfpropagating solution combustion method. It is shown that in one stage it is possible to obtain a nanopowder with a share of the $\mathrm{BiFeO}_{3}$ phase of $93 \%$. Heat treating at 450, 550, 600 ${ }^{\circ} \mathrm{C}$ allows to reduce the proportion of the parasitic phase up to $1 \%$. Further heat treating at $650{ }^{\circ} \mathrm{C}$ leads to its increase to $\sim 10 \%$, and above $650{ }^{\circ} \mathrm{C}$ to the decomposition of the main phase and, accordingly, to an increase in the share of parasitic phases.It has been obtained that with increasing of the $\mathrm{BiFeO}_{3}$ powder heat treating temperature, the crystallite size and optical band gap increase.It is established that theheat treating temperature significantly affects the photocatalytic oxidation of MO. It was shown that the main route of decomposition of $\mathrm{MO}$ is oxidation by hydroxyl radicals.

This work was supported by the Scholarship of the President of the Russian Federation No. SP-522.2018.1. All studies were conducted using the instrumental base of the collective center «Analytical Spectroscopy»and Scientific-Educational Center «nanotechnology» of Dagestan State University.

\section{REFERENCES}

1. Rauf M.A., Meetani M.A., Hisaindee S. An overview on the photocatalytic degradation of azo dyes in the presence of $\mathrm{TiO}_{2}$ doped with selective transition metals. Desalination. 2011, vol. 276, no. 1-3, pp. 13-27.

2. Akpan U.G., Hameed B.H. Parameters affecting the photocatalytic degradation of dyes using $\mathrm{TiO}_{2}$-based photocatalysts: A review. Journal of Hazardous Materials. Elsevier, 2009, vol. 170, no. 2-3, pp. 520529.

3. Konstantinou I.K., Albanis T.A. $\mathrm{TiO}_{2-}$ assisted photocatalytic degradation of azo dyes in aqueous solution: kinetic and mechanistic investigations. Appl. Catal. B Environ. 2004, vol. 49, no. 1, pp. 1-14.

4. Borker P., Salker A.V. Photocatalytic degradation of textile azo dye over $\mathrm{Ce}_{1}$.
${ }_{\mathrm{x}} \mathrm{Sn}_{\mathrm{x}} \mathrm{O}_{2}$ series. Mater. Sci. Eng. B SolidState Mater. Adv. Technol. 2006, vol. 133, no. 1-3, pp. 55-60.

5. Zubair Alam M., Ahmad S., Ahmad M. Mutagenicity and genotoxicity of tannery effluents used for irrigation at Kanpur, India. Ecotoxicol. Environ. Saf. 2010, vol. 73, no. 7, pp. 1620-1628.

6. O'Neill C., Lopez A., Esteves S., Hawkes F.R., Hawkes D.L., Wilcox S. Azo-dye degradation in an anaerobic-aerobic treatment system operating on simulated textile effluent. Appl. Microbiol. Biotechnol. 2000, vol. 53, no. 2, pp. 249254.

7. Mamba G., Mishra A. Advances in Magnetically Separable Photocatalysts: Smart, Recyclable Materials for Water Pollution Mitigation. Catalysts. 2016, vol. 
6, no. 6, pp. 79 .

8. Wang X., LinY., DingX., Jiang J. Enhanced visible-light-response photocatalytic activity of bismuth ferrite nanoparticles. J. Alloys Compd. 2011, vol. 509, no. 23, pp. 6585-6588.

9. Huo Y., Jin Y., Zhang Y. Citric acid assisted solvothermal synthesis of $\mathrm{BiFeO}_{3}$ microspheres with high visible-light photocatalytic activity. J. Mol. Catal. A Chem. 2010, vol. 331, no. 1-2, pp. 15-20.

10. Yonggang W., Gang X., Zhaohui R., Xiao W., Wenjian W., Piyi D., Ge Sh., Gaorong H. Low temperature polymer assisted hydrothermal synthesis of bismuth ferrite nanoparticles. Ceram. Int. 2008, vol. 34, no. 6, pp. 1569-1571.

11. Sanjay G., Nidhi S., GeetaR., Kumar B. Combined structural, electrical, magnetic and optical characterization of bismuth ferrite nanoparticles synthesized by autocombustion route. J. Asian Ceram. Soc. Elsevier, 2014, vol. 2, no. 4, pp. 416421.

12. Tang P., Kuang D., Yang Sh., ZhangY. The structural, optical and enhanced magnetic properties of $\mathrm{Bi}_{1-\mathrm{x}} \mathrm{Gd}_{\mathrm{x}} \mathrm{Fe}_{1-\mathrm{y}} \mathrm{Mn}_{\mathrm{y}} \mathrm{O}_{3}$ nanoparticles synthesized by sol-gel. $J$. Alloys Compd. 2015, vol. 622, pp. 194199.

13. Han Y.L., Liu W.F., Wu P., Xu X.L., Guo M.C., Rao G.H., Wang S.Y. Effect of aliovalent $\mathrm{Pd}$ substitution on multiferroic properties in $\mathrm{BiFeO}_{3}$ nanoparticles. $J$. Alloys Compd. 2016, vol. 661, pp. 115121.

14. Gao T., Chen Z., Zhu Y., Niu F., Huang Q., Qin L., Sun X., Huang Y. Synthesis of $\mathrm{BiFeO}_{3}$ nanoparticles for the visible-light induced photocatalytic property. Mater. Res. Bull. Pergamon, 2014, vol. 59, pp. 612.

15. Liu Z., Qi Y., Lu C. High efficient ultraviolet photocatalytic activity of $\mathrm{BiFeO}_{3}$ nanoparticles synthesized by a chemical coprecipitation process. J. Mater. Sci. Mater. Electron. 2010, vol. 21, no. 4, pp. 380-384.

16. Li S., Nechache R., Davalos I., Goupil G., Nikolova L., Nicklaus M., Laverdiere
J., Ruediger A., RoseiF. Ultrafast microwave hydrothermal synthesis of $\mathrm{BiFeO}_{3}$ nanoplates. J. Am. Ceram. Soc. 2013, vol. 96, no. 10, pp. 3155-3162.

17. Hengky C. Evidence of high rate visible light photochemical decolourisation of Rhodamine $\mathrm{B}$ with $\mathrm{BiFeO}_{3}$ nanoparticles associated with $\mathrm{BiFeO}_{3}$ photocorrosion. RSC Adv. 2012, vol. 2, no. 31, p. 11843.

18. Deganello F., Marcì G., Deganello G. Citrate-nitrate auto-combustion synthesis of perovskite-type nanopowders: a systematic approach. J. European Ceram. Soc. 2009, vol. 29, pp. 439-450.

19. Thoda O., Xanthopoulou G., Vekinis G., Chroneos A. Review of Recent Studies on Solution Combustion Synthesis of Nanostructured Catalysts. Adv. Eng. Mater., 2018, vol. 20, pp. 1800047.

20. Jain S.R., Adiga K.C., Vemeker V.R.P. A new approach to thermochemical calculations of condensed fuel-oxidizer mixtures. Combust. Flame. 1981, vol. 40, pp.71-79.

21. Patil K.C., Hegde M.S., Rattan T., Aruna S.T. Chemistry of Nanocrystalline Oxide Materials: Combustion Synthesis, Properties and Applications. World Scientific Publishing Co.: Singapore. 2008.

22. Kumar A., Rai R.C., Podraza N.J. Linear and nonlinear optical properties of $\mathrm{BiFeO}_{3}$. Appl. Phys. Lett. 2008, vol. 92, p.121915.

23. Ihlefeld J.F., Podraza N.J., Liu Z.K. Optical band gap of $\mathrm{BiFeO}_{3}$ grown by molecular-beam epitaxy. Appl. Phys. Lett. 2008, vol. 92, p. 142908.

24. Basu S.R., Martin L.W., Chu Y.H. Appl. Phys. Lett. 2008, vol. 92, p. 091905.

25. Arora M., Kumar M. Structural, magnetic and optical properties of $\mathrm{Ce}$ substituted $\mathrm{BiFeO}_{3}$ nanoparticles. Ceram. Int., 2015, vol. 41, pp.5705-5712.

26. Soltani T., Entezari M.H. Photolysis and photocatalysis of methylene blue by ferrite bismuth nanoparticles under sunlight irradiation. J. Mol. Catal. A Chem. 2013, vol. 377, pp. 197-203.

27. Xu Y., Schoonen M.A. The absolute energy positions of conduction and valence bands of selected semiconducting 
minerals. American Mineralogist. 2000, vol. 85, pp. 543-556.

28. White F.A. Mass Spectrometry in Science and Technology.1968., John Wiley \& Sons, Inc., New York, p. 343.

29. Hotop H., Lineberger W.C. Binding
Energies in Atomic Negative Ions. J. Phys. Chem. Ref. Data. 1975, vol. 4, pp. 539.

30. Kumar S., Koteswara K.S.R. Tungstenbased nanomaterials $\left(\mathrm{WO}_{3} \& \quad \mathrm{Bi}_{2} \mathrm{WO}_{6}\right)$ : Modifications related to charge carrier transfer mechanisms and photocatalytic applications. Applied Surface Science. 2015, vol. 355, pp. 939-958.

\title{
СИНТЕЗ И ИССЛЕДОВАНИЕ СВОЙСТВ МАГНИТНО-РАЗДЕЛЯЕМОГО НАНОФОТОКАТАЛИЗАТОРА ВіFеО
}

\author{
Ф.Ф. Оруджев ${ }^{1}$, Н.М-Р. Алиханов ${ }^{1,2}$, М.Х. Рабаданов ${ }^{1}$ Ш.М. Рамазанов ${ }^{1}$, А.Б. Исаев ${ }^{1}$, С.Х. \\ Гаджимагомедов ${ }^{1}$, А.Н. Алиев ${ }^{3}$, В.Р. Абдуллаев ${ }^{1}$ \\ ${ }^{1}$ ФГБОУ ВО «Дагестанский государственный университет» \\ 67000 Россия, Республика Дагестан, Махачкала, ул.Гаджиева, 43-а \\ e-mail:ff.orudzhev@dgu.ru \\ ${ }^{2}$ Институт физики им. Х.И. Амирханова ДНЦ РАН, Махачкала, Россия \\ ${ }^{3}$ Институт Катализа и Неорганической Химии им. акад. М. Нагиева, \\ AZ 1143 Баку, пр.Г.Джавида, 113; e-mail:kqki@kqki.science.az
}

В работе предложен простой и быстрый одноэтапный метод синтеза магнитно-разделяемого нанофотокатализатора $\mathrm{BiFeO}_{3}$ методом самораспространяющегося горения растворов. Показано, что данным методом можно синтезировать фазово-однородный и мелкодисперсный нанопорошок с долей фазы $\mathrm{BiFeO}_{3}$ 99\%. Исследовано влияние температуры термообработки на морфологию, структуру и оптические свойства $\mathrm{BiFeO}_{3}$. Установлены оптимальные параметры температуры термообработки для применения $\mathrm{BiFeO}_{3}$ в качестве фотокатализатора. Используя теорию электроотрицательности Малликена, был установлен возможный механизм разложения метилоранжа (МО). Показано, что наиболее вероятным является окисление МО гидроксильными радикалами.

Ключевые слова: феррит висмута, нанофотокатализ, горение, магнитная сепарация, электроотрицательность, гидроксильный радикал, химия пропеллента.

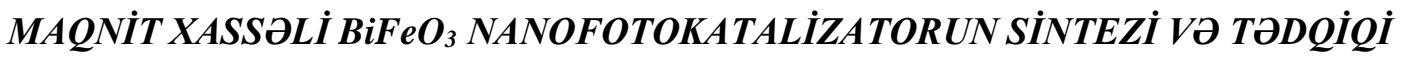

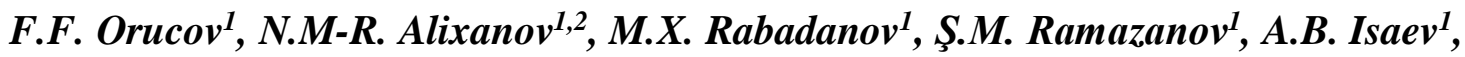 \\ S.X. Qadzhimagomedov ${ }^{I}$, A.Ş. Oliyev ${ }^{3}$, V.R. Abdullaev ${ }^{I}$
}

\section{Dă̆lstan Dövlat Universiteti}

67000 Rusiya, Maxaçqala, Haclyev küç, 43-a, e-mail: ff.orudzhev@dgu.ru DEM X.I. Omirxanov ad. Fizika Institutu, Rusiya, Maxaçqala AMEA-nın akad. M.Nağıyev adına Kataliz va Qeyri-üzvi Kimya İnstitutu AZ 1143, Bakl, H.Cavid pr., 113; e-mail: e-mail:akifaliyev55@mail.ru

\begin{abstract}
Maqnit xassali $\mathrm{BiFeO}_{3}$ nanofotokatalizatorun sadə, birmərhələli - məhlulların öz-özünə alışma sintez metodu taklif olunur. Göstarilib ki, bu metodla xirdadispersl, homogen fazall нано $\mathrm{BiFeO}_{3}$ sintez etmək mümkündür. Alınan maddənin morfologiyasina, guruluşuna va optik xassalarina emal temperaturunun təsiri öyranilmişdir. Alınan bismut ferritin fotokatalizator kimi istifadəsi üçün optimal emal temperaturu müəyyən edilmişdir. Mallikenin elektromənfilik nəzəriyyasindən istifadə edərək metiloranjın mümkün ola bilan parçalanma mexanizmi müəyyən edilib.
\end{abstract}

Açar sözlar: bismut ferrit, nanofotokataliz, yanma, elektromənfilik 